Published on Reviews in History (https://reviews.history.ac.uk)

\title{
See You In The Streets: Art, Action, and Remembering the Triangle Shirtwaist Factory Fire
}

Review Number: 2144

Publish date: Thursday, 3 August, 2017

Author: Ruth Sergel

ISBN: 9781609384173

Date of Publication: 2016

Price: $£ 15.82$

Pages: 194pp.

Publisher: University of Iowa Press

Publisher url: http://www.uiowapress.org/books/2016-spring/see-you-streets.htm

Place of Publication: Iowa City, IA

Reviewer: Chloe Ward

On 25 March 1911, a fire broke out on the eighth floor of the Asch Building in Greenwich Village, New York, and quickly began to spread. This floor, as well as the ninth and tenth, housed the Triangle Waist Company, a sweat shop producing ladies' blouses. An insurance inspector had previously noted spilled machine oil soaking the floor and heaps of flammable cotton scraps under the work tables. His recommendation that fire drills be conducted went unheeded by the factory bosses. So when the fire rapidly engulfed the factory, chaos reigned. Desperate to escape, workers on the ninth floor found that the door to the staircase had been locked, trapping them inside. One fire escape led to a dead end over a skylight several floors below. When the fire engines arrived, their ladders could only reach the sixth floor, well below the inferno raging above. When the fire drove trapped workers to the perimeter of the building, they began leaping out of windows, chased by licks of flame. 146 Triangle workers perished, the vast majority of them women, nearly all of them teenagers or very young adults, many being recent immigrants, and large numbers coming from the local Italian and Jewish communities of the Lower East Side. Their loss sparked a labour movement, workplace safety reforms, and strengthened workers' unions, transforming the landscape for labourers in modern America. But the fire also transformed families, and fundamentally reshaped the community of lower Manhattan as it responded to the loss over the subsequent months, years, and generations. 
Ruth Sergel's book, See You in the Streets: Art, Action, and Remembering the Triangle Shirtwaist Factory Fire, recounts her efforts to commemorate the fire through a series of interlinked art projects-cum-social interventions. Capturing both sides to the story - the desire to memorialise the fire as a socio-political event as well as a personal and emotional one - Sergel's book is a case study in how to do art activism well. Sergel, a filmmaker and multimedia artist, has orchestrated a number of other social engagement projects including an oral history of September 11, an interactive documentary about the 2011 massacre of striking miners in Kazakhstan, and a public intervention on the destruction of Gaza.(1)See You in the Streets draws on her expertise as an artist and social activist to chronicle the process of conceptualising and creating memorials to the Triangle Shirtwaist Factory Fire, projects that involved hundreds of participants and galvanised both local and distant communities to take actions that would commemorate the fire and recognise the event's reverberations in modern society.

Through a project called Chalk (2), which she outlines in the book, Sergel annually orchestrates a vast group of volunteers to commemorate the fire on its anniversary. On the pavement outside the former home of each Triangle victim, volunteers inscribe in chalk the worker's name, age, and cause of death, creating a network of sites of memory that extends throughout the city, radiating from a locus in the Lower East Side and broadening out through Brooklyn, the Bronx, and even New Jersey. The project makes the victims visible, reminding passers-by of their lives, not only their deaths, and represents the integral, if ephemeral, way in which each victim constituted a part of the wider cultural fabric of the city. Remember the Triangle Fire Coalition (3) grew out of Chalk, ultimately expanding into a national network that ramped up tributes to the fire in the lead up to its centenary in 2011. Coordinating a broad range of educational events, memorials, and activist and artistic interventions, the Coalition culminated in a centennial march that drew thousands to the base of the building where the blaze occurred, today occupied by New York University classrooms and science laboratories. To involve those who could not be in New York that day, the Coalition invited participants around the world to ring a bell at 4:45pm, marking the moment that the first alarm was sounded. Sergel's projects to commemorate the Triangle Shirtwaist Factory Fire presented diverse opportunities for collective remembrance, strengthening historical consciousness of the fire while simultaneously enrolling participants in the creation of new memories that extended the event's political and personal legacies.

See You in the Streets, as Sergel acknowledges, is not a history of either the Triangle Shirtwaist Factory Fire or of the projects she spearheaded to memorialise it. Although the book is indeed filled with history, and concluded with not inconsequential endnotes, it reads as a hybrid of two other genres: the memoir and the artist's book. As a memoir, it records Sergel's own aims and efforts to bring the projects to fruition, documenting both the successes as well as the failures. Perhaps most potently, she recounts with humour, honesty, and modesty her own tottering first steps as a leader. In spite of her efforts to create an entirely egalitarian and inclusive alliance with her Coalition collaborators, as the project grew, Sergel came to realise that pleasing everyone had become an unreasonable expectation-consensus is simply not always possible; what the organisation actually needed was for her to take ownership of her role as a leader, giving direction and structure to the whole. As a memoir that recognises the personal as intrinsic to the political, See You in the Streets is the kind of record I wish previous generations of art activists had kept. My own research on the art produced by political groups in the late 19th and early 20th centuries necessitates piecing together fragmentary evidence to reconstruct artists' aims and working processes. In contrast, Sergel's book presents her aims and working processes comprehensively, with clarity and nuance, and will doubtless represent a valuable cache of evidence for future historians working on 21st-century art activism.

The memoir-like quality to See You in the Streets positions the book squarely within the expanding category of work on contemporary art activism, which, as it develops, seems to be turning increasingly towards studies emphasising subjective, on-the-ground narratives by art creators and curators. Within this genre, even publications that are intended as popular history tend to not shy away from theoretical frameworks familiar to historians and art historians, and attempt to find ways to make them digestible to an educated nonexpert audience. Ai Weiwei's Spatial Matters: Art Architecture and Activism (4), for instance, uses interviews, blog posts, and critical essays to contextualise his artistic practice within overriding notions of 
'space', demonstrating how his work engages with spaces of increasing scale from the architectural to the geographical, digital, and social. Another example, Seeing Power: Art and Activism in the 21st Century (5) by the curator and activist Nato Thompson, frames its discussion around Antonio Gramsci's writings on hegemony, arguing for the creation of counter-hegemonic activist spaces and practices that have the capacity to evade entrenched beliefs and open new channels for cultural and political production.

Sergel's book never professes to be as theory-laden as these texts, yet I often wished it openly acknowledged or analysed the implications of some of its most recurrent theoretical referents. For instance, Sergel proclaims that Chalk is based on the premise of 'collective memory' (pp. 22, 36, 49) but never fully elaborates the concept, avoiding drawing explicitly on the work of its pioneer Maurice Halbwachs or addressing subsequent developments of his theories that have been used in other work on memory and commemoration. Sergel also repeatedly - albeit implicitly - invokes Michel Foucault, referencing, for example, the way in which those in power keep the populace 'docile' through political and social stratagems (p. 116), but she fails to expand on what a Foucauldian reading of her work might signify. Perhaps such theories have simply become the hackneyed and unexamined discourse of activism or art writing. Yet failing to situate her work more concretely within (or, even, against) the developing genre of art activism studies, as well as the theoretical frameworks being used in these investigations, is a missed opportunity for Sergel to articulate a broader argument about her work's place in the tide of artistic and political history.

This fault may be forgiven if we consider See You in the Streets as something other than a memoir of art activism: namely, as an artist's book - that is, a book that is an artwork in and of itself. The book's structure mirrors Sergel's approach to the art projects she describes in its pages, emphasising collectivity and acknowledging diverse voices. Interspersed between each chapter are what she refers to as 'postcards' from Coalition partners, short essays by artists, academics, poets, playwrights, and union organisers, amongst others, that relay personal narratives of their involvement in the Triangle commemoration projects. Picking up on themes or events discussed in the surrounding chapters, these insertions feel at times seamless and, at other moments, pleasingly discordant with Sergel's own account, disturbing the illusion that any singlyauthored description of events could ever represent a totalising narrative. Surely this is precisely the point Sergel aimed to make through the activities of the Coalition. Staging conversations and events that catered to participants' diverse needs and motivations - serving victims' families, labour union members, feminists, and activists, to mention only a few - the Triangle fire commemorations offered the opportunity for participants to 'author' their own unique experiences of memorialisation. In addition to mirroring Sergel's own artistic approach, the book also functions as a memorial, itself. Names and ages of the Triangle dead appear in the margin of every page, simultaneously individualising each victim as well as making visible the sheer extent of the fire's toll as each page turns. Whether or not we participated in Chalk or any of the Coalition's projects, the process of reading the book - turning these pages one by one, reading the name of each victim - allows the reader to join equally in an act of remembrance, enrolling us as participants in the network of collective memory Sergel continues to forge in commemorating the Triangle Shirtwaist Factory Fire. Finally, although Sergel's projects on the fire tended to emphasise a participatory form of art activism over more visual forms, the book draws on the significant role of the visual in her other work as a documentarian and filmmaker. Abundant images fill the pages, with photographs of the Chalk project and other contemporary interventions interspersed with haunting images of the victims, scenes from the factory, and pictures of the 1911 funeral procession that provided a model for the centennial march. The photographs reproduce in visual form the 'vibration between past and present' that Sergel hoped to stir through all her projects (p. 23).

If we consider the book to be, in its way, a work of art, its greatest strength is that it succeeds in doing what great works of art do so effectively - that is, allow us to see our own time with greater clarity. Sergel deftly points readers to the fire's modern resonances without hitting us over the head with them, drawing ongoing issues of workplace safety together with global economic inequality, the unjust treatment of (and lack of accountability for) today's overseas garment workers, as well as New York's other great tragedy, the events of September 11. As she poignantly notes, the Triangle fire and September 11 are especially linked through 
the experiences of their witnesses, who both reported the same overwhelming helplessness as they watched people make the choice to escape the flames by climbing out of windows, leaping to their deaths. As Sergel reminds us, we are all historical witnesses to a host of everyday tragedies and social injustices. Yet See You in the Streets also affirms our agency, calling on us to recognise social injustice and direct our anger and despair into action. History must never be symbol of hardships overcome, Sergel affirms, but rather a platform to inspire reflection, discussion, and action in the present.

\section{Notes}

1. Voices of 9.11 (2002-3 and 2011); Zhanaozen (2012); Gaza Ghetto (2014). Back to (1)

2. Chalk (2004-present).Back to (2)

3. Remember the Triangle Fire Coalition (2008-present, with Sergel at the helm until 2011).Back to (3)

4. Ai Weiwei, Spatial Matters: Art Architecture and Activism (Cambridge, MA, 2014).Back to (4)

5. Nato Thompson, Seeing Power: Art and Activism in the 21st Century (Brooklyn, NY, 2015).Back to $\underline{(5)}$

Source URL:https://reviews.history.ac.uk/review/2144

\section{Links}

[1] https://reviews.history.ac.uk/item/192671 